Available Online : https://proceeding.researchsynergypress.com/index.php/cset/index

RSF Conference Series: Engineering and Technology

ISSN 2809-6843 (Online) | 2809-6878 (Print)

Volume 1 Number 1 (2021): 399-406

\title{
UPN “Veteran” Yogyakarta’s Land Asset Area Planning in Semanu Gunung Kidul, Yogyakarta
}

\author{
Ediyanto ${ }^{1}$, Sugeng 2 , Hadi AN ${ }^{3}$, Dewanto $\mathrm{RH}^{4}$, Rifai $\mathrm{N}^{5}$, Safii HH' ${ }^{6}$, Brilian MY7 ${ }^{7}$ Nurmaulana $\mathrm{M}^{8}$, \\ Afifah L' ${ }^{9}$, Arthatia BS ${ }^{10}$, Putri SB11 \\ 1 Lecturer, Geomatics Engingeering, UPN “Veteran” Yogyakarta, Indonesia; \\ 2 Lecturer, Geological Engineering, UPN “Veteran” Yogyakarta, Indonesia; \\ 3, 4, 5, 6, 7, 8, 9, 10, 11 Student, Geomatics Engineering, UPN “Veteran” Yogyakarta, Indonesia
}

\begin{abstract}
Land is an asset in today's era of development. A patch of land's management must be planned so that its utilization can be done proportionally and professionally. The Special Region of Yogyakarta, namely Gunung Kidul Regency, has yet to have a reliable base map with high accuracy for each patch of land within its area, which results in the hampering of land use due to the lack of spatial information available. The lack of clear status and spatial information is felt by UPN "Veteran" Yogyakarta that has several patches of land in Gunung Kidul Regency, namely Kuwon Kidul, Pacarejo, Semanu, Gunung Kidul Regency. This research will create a base map scaled to 1:500 accompanied with information about height differences of said area and a recommended planning area considering three different aspects: geology, environment, and agriculture. The creation of a topographic map is useful for construction planning that will be conducted in the area. During this research, the topographic measurement and data processing were done in 11 days on field. The topographic measurement and data processing were conducted through five stages: initial survey, GNSS measurement, detail measurement, and data processing using software to produce a topographic map. The map result and measurement on field using Total Station showed that UPN "Veteran" Yogyakarta does not have a level surface and has good data density.
\end{abstract}

Keywords: planning area, asset, UPN “Veteran” Yogyakarta

\section{INTRODUCTION}

This is an open access article under the CC-BY-NC license

Land is an asset in today's era of development. A patch of land's management must be planned so that its utilization can be done proportionally and professionally. Additionally, a patch of land has legal force, which makes definite spatial information regarding it is necessary to conduct construction planning there. Spatial information can be delivered using a reliable base map with high accuracy.

The Special Region of Yogyakarta, namely Gunung Kidul Regency, has yet to have a reliable base map with high accuracy for each patch of land within its area, which results in the hampering of land use practices due to the lack of spatial information available. The lack of clear status and spatial information is felt by UPN "Veteran" Yogyakarta that has several patches of land in Gunung Kidul Regency, namely di Kuwon Kidul, Pacarejo, Semanu, Gunung Kidul Regency. The asset is still in the form of a forest that has yet to be utilized optimally.

The patch of land owned by UPN "Veteran" Yogyakarta in 2014 consisted of 20 plots, while in 2018 consisted of 37 plots. As of now, all plots are still abandoned, and the assets are simply based on the area noted on the old land certificate. According to Peraturan Pemerintah tentang Penyelenggaraan Penataan Ruang, Hak Pengelolaan, Hak Atas Tanah, Satuan Rumah Susun dan Pendaftaran Tanah, Penyelenggaraan Pengadaan Tanah untuk Kepentingan Umum dan Peraturan Pemerintah tentang Kawasan dan Tanah Terlantar which had been legalized, UPN as a state institute must conduct land use, land registration, land rechecking practices, and find out the actual size area of the land. In this case, the Geomatics Engineering study program especially the area mapping field plays a role in providing the area planning base data to conduct the area's situational measurement and mapping and the plots' topography so that those plots can be analyzed for future use by UPN's academic community. 
According to Peraturan Pemerintah Nomor 8 Tahun 2013 Pasal 1 Ayat 11 tentang Ketelitian Peta Rencana Tata Ruang, a base map is a map providing natural and or manmade resources, located on earth, drawn in a flat surface with certain scaling, numbering, projection, and georeferencing, so that a land has a clear border and area. According to the regulation, a measurement must be done to make a base map so one can find out its area, beside its boundary. Data inventory as a base map is useful to make area planning. This research will produce a base map scaled to 1:500 accompanied with information regarding height differences in the area and a recommended area planning considering three aspects: geology, environment, and agriculture. The creation of topographic map is useful for construction planning that will be conducted in the area.

\section{LITERATURE REVIEW}

GNSS (Global Navigation Satellite System) is a satellite system consists of a constellation of satellites which provides information regarding time and location, which shoots many kinds of light in many frequencies constantly, and is available in many locations on earth. GNSS plays important role in navigation. GNSS that exists today are GPS (Global Positioning System) that is owned and managed by the United States of America; GLONASS (Global Navigation Satellite System) owned by Russia; Galileo owned by the European Union; and Compass or Beido owned by China. India and Japan are developing regional GNSS by launching several satellites to space to increase the current global system ability to allow them to cover regional areas [UNOOSA, 2011].

According to the American Society of Photogrammetry (ASP), photogrammetry is the art, science, and technology of obtaining reliable information about physical objects and the environment through process such as recording, measuring, and interpreting photographic images and patters of electromagnetic radiant energy and other phenomena. 'Photographic images' refers to aerial imagery, which is a record of some part of earth's surface obtained using camera planted in a body such as an aircraft. Further development of photogrammetry brings about an extended meaning of photogrammetry, which becomes the science and technology of aerial imagery processing to extract data and information for mapping and manipulating purposes (Suyudi, 2014). Photogrammetry or aerial surveying is a mapping technique through aerial imagery. The result of mapping photogrammetrically is a photographic map which cannot be used as a base or an inset of a published map. Photogrammetric mapping needs terrestrial measurement as a reference, from determining ground control points to measuring land boundaries. Land boundaries identified in a photographic map must be measured on field.

Detail is the natural or manmade appearance or feature that stands out in mapping area. Detail measurement is done by taking data from earth's physical surface which is considered as a representation above the map (Sinaga, 1997). Detail measurement is done to find 3D coordinates in planimetric and spotheight details. Planimetric details measured consist of street/road, buildings, rivers or gutters, electric poles, and others in accordance with the field's condition. Spot-height details are taken in points representing terrain shape, considering the vertical scale which will be used. Situation detail measurement is done by creating a new job in Total Station, entering benchmark's coordinate, setting up station and backsight in the benchmark being used, entering identification (code and number) of details that will be measured, and points the telescope to the target - a prism reflector held by the target's holder (Kavanagh, 2010).

\section{RESEARCH METHODOLOGY}

This research's methodology consists of preparation, measurement, data processing, and data presentation in the form of a topographic map. This research's location is in UPN "Veteran" Yogyakarta's asset in Semanu, Gunung Kidul, Yogyakarta. Preparation includes literature review, preparing the tools and material, preparing the funding, preparing the personnel, and preparing other necessities.

Basically, the tools used in a topographic measurement consist of two kinds of tools: measuring tools and data processing tools. The measuring tools consist of two sets of Total Station Topcon GTS-102N and Nikon DTM 322; three sets of GNSS Connav; and one set of Drone DJI Phantom 4 Pro. The data processing tools consist of one unit of laptop, Topcon Link, TransIt, Compass Receiver Utility, AutoCAD Civil 3D 2018, and Agisoft Metashape. 
Below is the topographic measurement and data processing steps:

\section{Initial Survey}

Initial survey includes location terrain's survey and land boundary survey in UPN "Veteran" Yogyakarta's asset in Semanu, Gunung Kidul, Yogyakarta. Furthermore, the planning of benchmark's installation locations and pegs is also done.

\section{Installing Pegs}

The pegs installed are benchmark (BM) and wooden pegs as an initial device. BM is made from concrete with paralon pipe as bekisting with a diameter of 3 inches and a height of 0,5 meter. BM is an initial reference point for every other measuring point where the TS will stand later. BM's coordinate is obtained from GNSS observation with static radial method from Geospatial Information Agency's BM CORS Station. There are two sets of BM or 4 points located within UPN "Veteran" Yogyakarta's asset in Semanu, Gunung Kidul, Yogyakarta. Meanwhile, the wooden pegs act as helping measurement points for the TS to stand, scattered in the surface of area measured. The wooden pegs coordinate is obtained from GNSS observation with static radial method from Geospatial Information Agency's BM CORS Station and TS.

\section{GNSS Measurement}

GNSS measurement was done in BM points and pegs using static radial method from Geospatial Information Agency's BM CORS. The pegs and BM made from before acted as initial reference points or control points while doing topographic measurement.

\section{Detail Measurement}

Detail measurement was done using two sets of Total Station-Topcon and Nikon-with tachymetry method. Detail measurement was taken in every difference in height, embankment, and land boundary, marked by concrete pegs.

5. Data Processing

Measurement results then was processed to create a topographic map. The software used are as listed below:

a. Topcon Link and TransIt

Topcon Link and TransIt were used to download measurement data from Total Station. Topcon Link was used to download measurement data from Topcon Total Station and Transit was used to download measurement data from Nikon Total Station.

b. Compass Receiver Utility

Compass Receiver Utility was used to change GNSS measurement data's format from Connav (.cnb) to GNSS standard format (Rinex). The purpose of transforming the format was so that the data could be processed online in Spider Business Center in the Geospatial Information Agency's website.

c. Spider Business Center

Spider Business Center was used to process baseline from GNSS data to gain coordinates.

d. Agisoft Metashape

Agisoft Metashape was used to process aerial pictures, starting from collating, creating orthophotos, and finalizing the aerial picture map.

e. AutoCAD Civil 3D 2018

AutoCAD Civil 3D was used to plot measurement data to make contours out of them before creating the topographic map.

\section{FINDING AND DISCUSSION}

\section{A. Finding}

\section{Result and Analysis GPS Observation Data}

From Data processing, the results obtained in the form of an overview of the baseline shape, coordinates X, Y, Z, standard deviation results and RMS from processing. Processing was performed by the radial method.

GPS Observation and Primary Data Collection. The following are the results of observations of the points designated as the start for topographic measurements, namely at points BM GM 007, GM 008, GM 009, GM 010 where observations were made for 2 hours. 
RSF Conference Series: Engineering and Technology

Vol 1 (1), 399-406

UPN “Veteran" Yogyakarta's Land Asset Area Planning in Semanu Gunung Kidul, Yogyakarta Ediyanto, Sugeng, Hadi AN, Dewanto RH, Rifai N, Safii HH, Brilian MY, Nurmaulana M, Afifah L, Arthatia BS, Putri SB

Table 1. Coordinate values dan Elevation BM GM

\begin{tabular}{cccc}
\hline Point & X & Y & Z \\
\hline GM007 & 457984.1231 & 9111751.8809 & 183.5176 \\
GM008 & 457946.4207 & 9111773.9323 & 182.5677 \\
GM009 & 458125.4068 & 9111653.7989 & 183.6883 \\
GM010 & 458107.8296 & 9111680.2006 & 187.8313
\end{tabular}

\section{Result and Analysis Aerial Photo Mapping}

From the mapping process using the DJI Phantom 4 Pro Obsidian Drone, it is processed using the Agisoft application to receive orthophoto aerial photos. The data that has been processed is obtained from orthophoto aerial photo images of the measurement locations as shown in Picture X. Aerial photo mapping uses the UTM coordinate system.

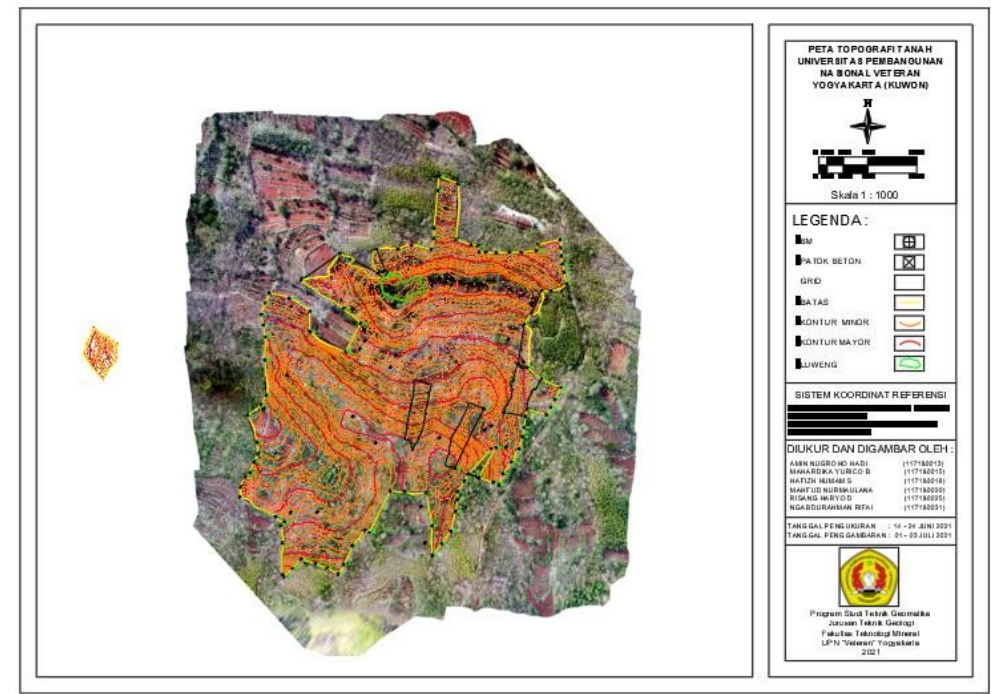

Figure 1. Aerial photo map of UPN land area boundaries

\section{Situation Measurement}

Data on the results of measurements in the field for 11 days with Total Station and prism tools. The data that has been taken will be downloaded using the Topcon Link and TransIT software. The downloaded data is in the form of $\mathrm{x}, \mathrm{y}$ and $\mathrm{z}$ coordinates (elevation). The $\mathrm{x}, \mathrm{y}$ and $\mathrm{z}$ (elevation) coordinate values include the Benchmark (BM), Peg (P) values.

The results of data collection in the field show that in the area of the measurement location there are 108 boundary markers marked from P1 to P108 and have 6332 detailed values (SH) marked from SH1 to SH6332 with additional 4 points of BM. Measurement of detail points and BM use the same coordinate system, namely the UTM coordinate system. 


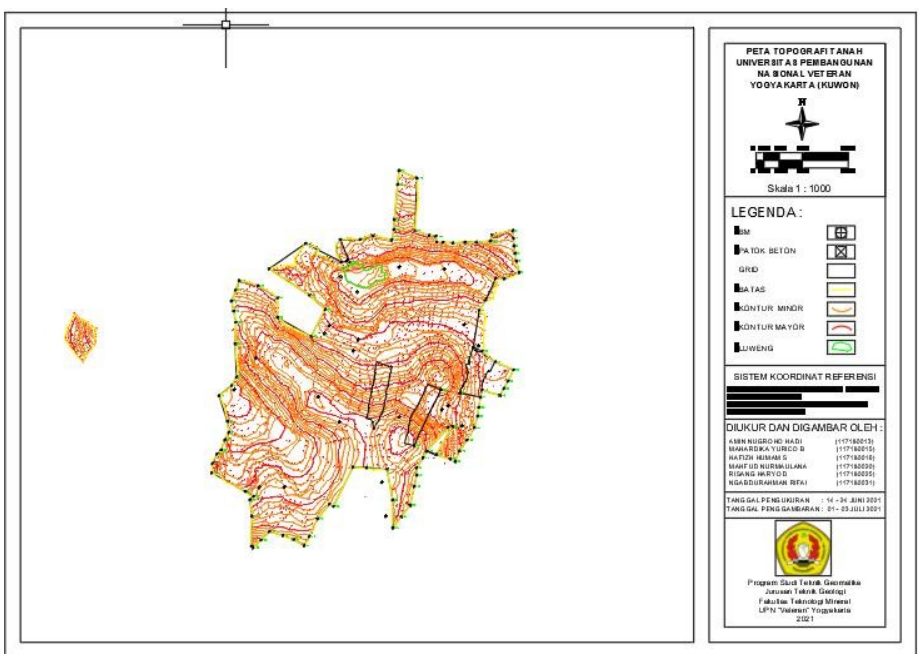

Figure 2.. Topographic map and UPN land area boundaries

The coordinates and elevation that have been obtained will be processed with Autodesk Civil 3D 2018 software to describe the measurement results. The results of the drawing with the Autodesk Civil 3D 2018 software can be seen above in the picture X.

\section{DISCUSSION}

BM data obtained from GNSS measurements using a reference point from the CSDG station. Because the location of the csdg station is the closest to the measurement location. So it is expected to get the most precise $\mathrm{x}, \mathrm{y}$, and $\mathrm{z}$ coordinates and have minimal corrections.

The image of the aerial photo map of the UPN land area is the result of mapping in the field using the DJI Phantom 4 Pro Obsidian Drone and has been processed using the Agisoft application to obtain orthophoto aerial photos. Aerial photo mapping uses the same coordinate system as the detailed situation measurements and BM measurements, namely the UTM coordinate system. Furthermore, the results from aerial photo mapping are used to assist the planning stage of measurements at the location.

Picture X. Topographic map and UPN land area boundaries is the result of mapping and field measurements using a total station tool using PRIMA. From the picture, it can be seen that the shape of the land surface belonging to the UPN area is not flat. Taking detail points follows the actual field conditions. So that the image can form an uneven ground surface as in its original location. The measurement location is a hilly area filled with hills and slopes so that only a few areas have flat elevations.

Topographical measurement data has a fairly good data density. The height value from the extraction of point clouds must have good accuracy so that the resulting contour lines have data quality that is not much different from the actual topographic conditions in the field. Topography measurements obtained from an area of land assets of 107,796,245 $\mathrm{m}^{2}$. Furthermore, the resulting topographic map can be used for area planning needs at that location 
1) Determining the Location of Pendopo on Asset Land of Yogyakarta UPN "Veteran" Yogyakarta

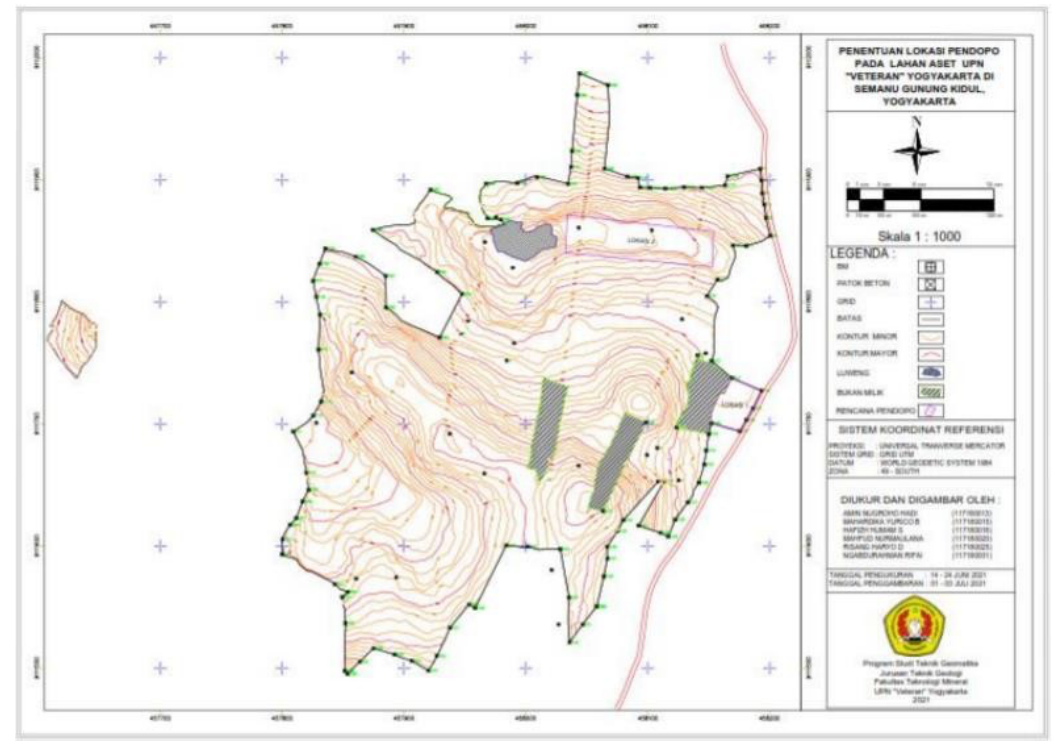

\section{Location 1:}

The reasons for determining the pendopo constraction at location 1 are as follows:

a. Location directly adjacent to the main road.

Location 1 is located on the edge of the UPN asset land which is directly adjacent to the main road, with this being an advantage because the planned location will be easily accessible, easy to find the location and access to the planned location is already availablecbecause it can take advantage of existing road access so there is no need to make a road to the location.

b. The area is relatively flat and wide.

Location 1 has a relatively flat and broad topography. The relatively flat area will be an advantage if the pendopo is to be built because it will be easier to carry out construction and will not require too much excavation or stockpiling when compared to other areas. Location 1 has an area of $\pm 1082.665 \mathrm{~m}^{2}$, with this area it is possible to build a pendopo and several other supporting buildings.

c. Security

If it is reviewed in the area there are no rubble rocks, this is also supported by a tiered form of land so that it will minimize the occurrence of landslides considering that the UPN asset land is in a hilly area. In addition, considering that the topography around the location has a difference in elevation which results in a slope, it can potentially become a water flow path when it rains so that it can be flooded, but this can be anticipated by making waterways on the outskirts of the area that are directed to a lower elevation.

d. Close to luweng

Close to luweng is also an advantage with the construction of the pendopo, which include:

Close to water sources, if the UPN can raise the water, it will be very useful for supporting development, implementation of activities and the surrounding community to take advantage of the existing water.

Luweng is one of the geological objects that need to be protected. By utilizing luweng and the area around luweng it will make it more well maintained. And seeing that luweng is one of the rare geological objects, then it can also have the potential to make it a geological tourism object which if it can be used properly it can also support the economy of the surrounding community.

\section{Location 2:}

The reason for determining the location is because it pays attention to several aspects, which include: 
a. The location is not far from the main road

The location distance from the main road is \pm 50 meters from the main road, from this it will be easier to reach the pendopo users both from the university and the surrounding community by making access roads to the location.

b. The area is relatively flat and wide. Location 2 has a relatively flat and wide area. The relatively flat area will be an advantage if the pendopo is to be built because it will be easier to carry out construction and will not require too much excavation or stockpiling when compared to other areas. The area that has been chosen has an area of 3643,884 $\mathrm{m}^{2}$, with this area it is possible to build a pendopo and several other supporting buildings.

c. Security

If viewed from the conditions in the area there is no rock debris, this is also supported by a tiered form of land so that it will minimize the occurrence of landslides considering that the UPN asset land is located in a hilly area. In addition, considering that the selected area has a relatively low elevation compared to its surroundings, it also has the potential to be inundated with water, but this can be anticipated by making waterways on the outskirts of the area directed to luweng.

d. Close to luweng

Close to luweng is also an advantage with the construction of the pendopo, which include:

- Close to water sources, if the UPN can raise the water, it will be very useful for supporting development, implementing activities and the surrounding community to take advantage of the existing water.

- Luweng is one of the geological objects that need to be protected. By utilizing luweng and the area around luweng it will make luweng more well maintained. And seeing that luweng is one of the rare geological objects, then it can also have the potential to make it a geological tourism object which if it can be used properly it can also support the economy of the surrounding community.

\section{CONCLUSION AND FURTHER RESEARCH}

The main conclusions of the study may be presented in a short Conclusions section, which may stand alone The conclusion obtained from this research is that the land assets of UPN "Veteran" Yogyakarta in Kuwon Kidul, Paddyjo, Semanu, Gunung Kidul, Yogyakarta have an area of 107,796.245 m². In this study, a discussion of the relatively steep topography and hilly area is presented which is also reflected in the contours on the resulting topographic map with the lowest elevation values of 165 masl and 210 masl. The results of this study can be used to support the planning of UPN "Veteran" Yogyakarta if it will carry out construction or development and all forms of activities that require information on the topography and area of the land asset area.

Data acquisition in this study also encountered a few obstacles, namely the existence of areas that are prone to data collection and uncertain weather. These obstacles can be used as learning materials so that in the future they can be better prepared for data collection in all fields and can manage time by paying attention to the weather so that it can run smoothly.

\section{REFERENCES}

Arfaini Juwita dan Hepi Hapsari, H. 2016. "Analisa Data Foto Udara untuk DEM dengan Metode TIN, IDW, dan Kriging”. Institut Teknologi Sepuluh November. Surabaya.

Basuki, S. (2011). Ilmu Ukur Tanah. Gadjah Mada University Press, Yogyakarta.

Darmo Yuwono, B., Amarrahman, F. J., \& Awaluddin, M. (2018). Analisis Perbandingan Ketelitian Metode Registrasi Antara Metode Kombinasi Dan Metode Traverse Dengan Menggunakan Terrestrial Laser Scanner Dalam Pemodelan Objek 3 Dimensi (Studi Kasus: Monumen Tugu Muda, Kota Semarang, Jawa Tengah). Doctoral dissertation : Universitas Diponegoro. 
RSF Conference Series: Engineering and Technology

Vol 1 (1), 399-406

UPN “Veteran” Yogyakarta's Land Asset Area Planning in Semanu Gunung Kidul, Yogyakarta Ediyanto, Sugeng, Hadi AN, Dewanto RH, Rifai N, Safii HH, Brilian MY, Nurmaulana M, Afifah L, Arthatia BS, Putri SB

Laboratorium Fotogrametri. 2019. Modul Praktikum Fotogrametri. Sekolah Tinggi Pertanahan Nasional : Yogyakarta.

Purworahardjo, U. (1989). Ilmu UkurTanah Seri C. Fakultas Teknik Sipil dan Perencanaan. Institut Teknologi Bandung, Bandung.

Tim Kuliah Lapangan TGM UPNVY. 2016. Buku Panduan Kuliah Lapangan. Program Studi Teknik Geomatika Jurusan Teknik Geologi Fakultas Teknologi Mineral UPN "Veteran” Yogyakarta : Yogyakarta.

(UNOOSA, 2011) 10 Years of achievment of the United Nations on Global Navigation Satellite Systems, New York 2011 